\title{
Learning Grammar Autonomously through Metacognitive Strategies: An Experiment
}

Stanley Mohandoss Stephen \& Xavier Pradheep Singh

Abstract

Knowing how to learn a language maximizes the chances of effective learning. Metacognition, an emerging concept in cognitive psychology, aids learners to enrich their knowledge of the learning process and makes them autonomous learners. This paper details an experiment conducted with fifty freshmen in college on autonomous learning of 'concord' using metacognitive strategies. This experiment is an attempt to verify whether students can learn English grammar autonomously when they are trained to use metacognitive knowledge and strategies. This experiment uses the method described by Best and Kahn (2000).

Key words: metacognitive knowledge, metacognitive strategies, learner autonomy

\section{Introduction}

Metacognition, as defined by Flavell, is

...one's knowledge concerning one's own cognitive processes and products or anything related to them ... [and] the active monitoring and consequent regulation and orchestration of these processes in relation to the cognitive objects or data on which they bear, usually in the service of some concrete goal or objective. (1976, p. 232)

Flavell talks about two major aspects of metacognition, namely, metacognitive knowledge ("knowledge concerning one's own cognitive processes") and the executive functions ("active monitoring and consequent regulation and orchestration" of cognitive processes). Moreover, he distinguishes three kinds of metacognitive knowledge:

Person knowledge - one's beliefs about the nature of oneself and others as cognitive processors (1979, p. 907).

Task knowledge - one's belief about the demands, goals, and nature of a particular task
Strategy knowledge - one's perception of the utility of a strategy.

Metacognitive strategies are general learning strategies. Wenden(1987), Nelson and Narens(1994), Chamot (1999) and Anderson (2002) have listed many learning strategies: planning, predicting, assessing prior knowledge, selecting appropriate strategies, monitoring comprehension, monitoring strategy use, problem solving, and evaluating the learning process. All these strategies can be grouped into four major categories: 1. planning, 2 . monitoring, 3. problem solving, and 4. evaluating. These strategies generally follow a sequential order even though metacognition need not be a linear process. In reality, one may go back and forth and use a particular strategy more than once. Previous studies show that there is a significant relationship between metacognition and second language learning. Goh and Taib (1997 \& 2006) discovered that many second language listeners are metacognitively aware. Muniz-Swicegood (1994) concluded that metacognitive strategies improve reading skills. Kaspar (1997) found out that metacognitive strategies influence writing performance. 


\section{Hypothesis}

In this experiment, the researchers hypothesized that the students can learn English grammar themselves successfully, if they are trained to use their metacognitive knowledge and strategies.

\section{Participants}

The researchers conducted an experiment among fifty students consisting of 43 boys and 7 girls. They were all freshmen in college majoring in Commerce at the American College, Madurai, South India. Their mean age was 18 years ranging from 17 to 20 . Their mother tongues were different; their medium of instruction in school was different; and the grades they obtained in their final exam at school were also different. But, all of them learn English as a second language at the undergraduate level.

\section{Materials}

Reflective questionnaire: A set of reflective questions were distributed among the subjects of the control group while learning concord. These questions allowed them to plan, monitor and evaluate.

Pre-test paper: The Pre-test paper consisted of twenty multiple choice questions on subject-verb concord. This test paper was used to form the experimental and control groups.

Post-test papers: Like the pre-test paper, the post-test papers I and II too had twenty multiple choice questions on 'subject-verb concord.' But in the post-test papers, students were conditioned not to make any guesses. That is, students should not attempt a question if they do not feel they know the answer. This condition is based on Nelson and Narens' (1994) idea of "feeling of knowing judgement" (p. 16). Feeling of knowing judgement is an estimation of "whether a given currently non recallable item is known and / or will be remembered on a subsequent retention test" ( $p$. $16)$.

\section{Methodology}

Five separate sessions were conducted on five different days for the experiment. In the first session, all the participants took a pre-test on 'concord' for twenty marks. Based on the pre-test scores, participants were divided into two equal groups (the experimental and the control group) through "matched randomization method" (Best, p.140). Therefore, both the groups consisted of 25 subjects and their mean score in the pre-test was 11.7.

The subjects in the experimental group alone were trained in the use of metacognitive strategies in the second session. The nature of metacognition and its three components were explained to them - person, task and strategy knowledge. Then the researchers demonstrated how to plan, monitor, solve a learning problem, and evaluate the learning process. But the subjects in the control group were not given any such training.

Both the groups were assigned the task of learning 'concord' in the third session. The subjects in the experimental group were given handouts on 'subject-verb concord' and were asked to learn it autonomously using metacognitive strategies. Subjects were allowed to interact among themselves. They were also given a set of reflective questions that led them to plan, monitor, problem-solve and evaluate their learning process. Conversely, the control group was taught 'subjectverb concord' in the conventional method. They just listened to the researchers for the explanation on concord. It was a teacher- centered class. Students were not introduced to the use of metacognitive strategies and they were not even allowed to interact among themselves.

Both the groups wrote two post-tests on 'concord' for twenty marks each in the fourth and fifth sessions. In order to avoid blind guesses, students were given a condition as mentioned earlier: If they did not feel like knowing the answer to a question, they should not attempt it.

\section{Result and Discussion}

Finally the scores of the students in all the three tests were analyzed in order to check the hypothesis putforth by the researchers. In the pretest, both the experimental and the control groups had obtained 11.7 as their mean score. But in the post-tests their mean scores made significant differences.

In the post-test I, the experimental group had obtained 12.52 as its mean score, ranging from 16 to 
9 which was $3.8 \%$ higher than the mean score in the pre-test. And the control group's mean score was 9.04, ranging from 17 to 1 which was $13.4 \%$ lower than the mean score in the pre-test. This decrease in the score might be attributed to the condition given in the post-tests. Due to the condition, students did not answer the questions which they did not feel they did not know the answer. But the answers they gave were almost correct.

In the post-test II, the experimental group had scored 14.84 as its mean, ranging from 18 to 10 which was $11.6 \%$ higher than its mean score in the post-test I. The control group had gained 10.92 as its mean score, ranging from 16 to 4 . It was $9.4 \%$ higher than its mean score in the post -test I. It was clear that both the groups had made improvements compared to the scores in the posttest I (illustration appended).

From the results, it is evident that the experimental group, which used metacognitive strategies, has performed better than the control group. The experimental group has also increased its mean scores in each test. Its mean score in the post-test I is $3.8 \%$ higher than that in the pre-test. Likewise its mean score in the post-test - II is $11.6 \%$ higher than that in the post test I. This proves the fact that the experimental group has used metacognitive strategies in the right way and that it has acquired metacognitive knowledge while evaluating the learning experience during each test. Thereby the subjects in the experimental group have gradually become experts in the use of metacognitive strategies. This can also be illustrated through the highest and the lowest scores they have received in the tests. The highest scores of the experimental group in each test are 16, 16 and 18 respectively in the pre-test, the post test I and II. The lowest scores are 7, 9 and 10 respectively in the pre-test, the posttest I and II. So it is evident that the experimental group has shown greater increase in its score. This increase can primarily be attributed to the use of metacognitive strategies. Students, who are trained in the use of metacognitive strategies, are able to plan, monitor and evaluate their learning. They easily identify where they have a problem in learning English grammar. This research shows that students can learn grammar autonomously if they are trained well in the use of metacognitive strategies. It is also clear that metacognition helps learners to regulate their learning process and that it maximizes learner autonomy in a grammar class.

\section{Conclusion}

Metacognition, a vital concept in cognitive psychology has demonstrated that learning about the learning process is an essential part of learning a language. Learners' knowledge about themselves as learners, their learning tasks and their use of appropriate strategies are vital components of metacognition. Intense research has proved that successful learners are those who are metacognitively aware to use appropriate learning strategies. The experiment cited above has proved that metacognitive instruction can lead to learner autonomy in language classroom. The scope of the experiment can be widened to include a bigger class of students across disciplines for a longer period of time. It is desirable for teachers of language to adopt the methods of metacognition such as modeling, scaffolding, self-questioning, problem-solving, reflection and response.

Dr. Stanley M. Stephen heads the Postgraduate and Research Department of English American College, Tamil Nadu, India. He has published many articles in ELT journals. His full- length book Bharati Mukheriee: A study in Immigrant Sensibility was published by Prestige Books, Delhi in 2010. Besides ELT courses, he teaches postcolonial poetry to postgraduate and pre-doctoral students. He writes and publishes poetry as well. Presently, he is supervising eight doctoral candidates.

Ms. Xavier Pradheep Singh is an assistant professor of English at $\mathrm{V} O$ Chidambaram College, Thoothukudi, South India. He holds an MPhil from the American College, M K University. His areas of interest include CALL (Computer Assisted Language Learning) and Postcolonial Studies. Pradheep Singh is the executive editor of Cuckoo, a student literary magazine. Presently, he is working on his doctoral research on Computer Assisted Language Learning

\section{References}

Anderson, N. J. (2002). The role of metacognition in second language teaching and learning. ERIC Digest, Apr. 2002. 3-4.

Best, J. W. \& Kahn, J. V. (2000). Research in education. ( $7^{\text {th }}$ ed). New Delhi: Prentice Hall of India.

Chamot, A. U. et al. (1999). The learning trategies handbook. London: Longman.

Flavell, J. H. (1976). Metacognitive aspects of problem solving. In L. B. Resnick (Ed.), The Nature of Intelligence (pp. 231-235). New Jersey: Lawrence Erlbaum.

Flavell, J. H. (1979). Metacognition and cognitive 
monitoring: A new area of cognitive developmental inquiry.American Psychologist, 34. 10. 906-911.

Goh. C. (1997). Metacognitive awareness and second language listeners. ELT Journal, 51. 4. 361-369.

Goh. C. \& Taib, Y. (2006). Metacognitive instruction in listening for young learners. ELT Journal, 60/3, 222-232.

Kaspar, L. F. (1997). Assessing the metacognitive growth of ESL student writers. TESL-EJ. 3. 1.

Muniz-Swicegood, M. (1994). The effects of metacognitive reading strategy training on the reading performance and student reading analysis strategies of third grade bilingual students. Bilingual Research journal, 18. 1 \& 2. 83-97.

Nelson, T. O. \& Narens, L. (1994). Why investigate metacognition? In J. Metcalfe \& A. Shimamura (Eds.), Metacognition: Knowing about Knowing (pp. 1-10). Cambridge: MIT Press.

Wenden, A. (1987). Metacognition: an expanded view on cognitive abilities of L2 learners. Language Learners, 37. 1. 573-596.

\section{Appendix}

\section{Reflective Questions for the Experimental Group}

I Planning:

(1) What is the given task?

(2) Do I already know anything about this particular task?

(3) What is my learning goal here?

(4) How much time do I need to complete the task?

(5) What are my plans in accomplishing this task?

II Monitoring:

(1) Do I know this already?

(2) Have I understood?

(3) If not, what am I going to do?

(4) Should I revise my plan?

(5) Should I ask for help?

III Evaluation:

(1) Have I understood everything completely?

(2) If not, what do I need to do?

(3) Have I achieved my goal?

(4) Did my plan work?

(5) What are the strategies I worked out here?

(6) Do I need to go back to the task to fill in any blanks in my understanding? 
Table 1

\section{Descriptive analysis of the test scores of both the groups}

\begin{tabular}{|l|l|l|l|l|l|l|}
\hline \multicolumn{1}{|c|}{ Tests } & \multicolumn{1}{|c|}{ Groups } & $\begin{array}{c}\text { Mean score } \\
\text { (out of 20) }\end{array}$ & \multicolumn{1}{|c|}{ percentage } & \multicolumn{1}{|c|}{ Range } & \multicolumn{1}{c|}{$\begin{array}{c}\text { Highest } \\
\text { score }\end{array}$} & \multicolumn{1}{c|}{$\begin{array}{c}\text { Lowest } \\
\text { score }\end{array}$} \\
\hline \multirow{2}{*}{ Pre-test } & Experimental group & 11.7 & $58.5 \%$ & 9 & 16 & 7 \\
\cline { 2 - 8 } & Control group & 11.7 & $58.5 \%$ & 10 & 16 & 6 \\
\hline \multirow{2}{*}{ Post Test - I } & Experimental group & 12.52 & $62.6 \%$ & 7 & 16 & 9 \\
\cline { 2 - 8 } & Control group & 9.04 & $45.2 \%$ & 16 & 17 & 1 \\
\hline \multirow{2}{*}{ Post Test - II } & Experimental group & 14.84 & $74.2 \%$ & 8 & 18 & 10 \\
\cline { 2 - 8 } & Control group & 10.92 & $54.6 \%$ & 12 & 16 & 4 \\
\hline
\end{tabular}

Note. This table lists out the mean scores of the experimental group as well as the control group. It also presents the highest and the lowest scores in both the groups in all the three tests.

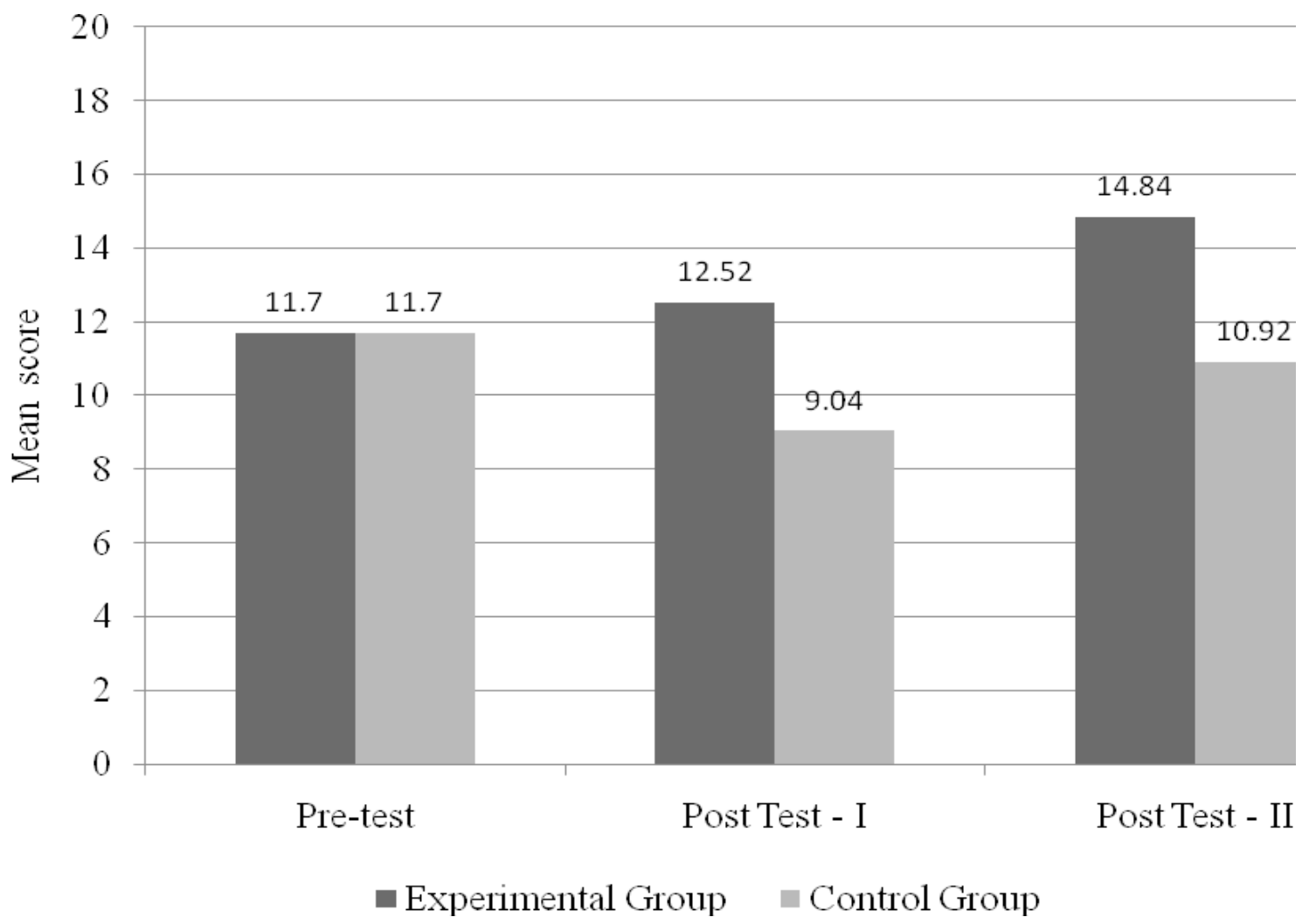

Figure 1. Mean scores of both the control group and the experimental group in all the three tests. The experimental group shows greater increase in its scores whereas the control group is slow in its increase. 